\title{
Ethical but Upsetting Geoscience Research: A Case Study
}

\author{
THOMAS PÖLZLER \\ Institute of Philosophy, University of Graz, Austria \\ thomas.poelzler@uni-graz.at \\ FLORIAN ORTNER \\ Department of Geography and Regional Science, University of Graz, Austria \\ FWF-DK Climate Change, University of Graz, Austria \\ florian.ortner@uni-graz.at
}

\begin{abstract}
Geoscience research may upset people even though it is ethically acceptable. In this paper we attempt to explore three questions about such research. It will turn out that (1) under most circumstances ethical but upsetting geoscience research is morally permissible, (2) revising this research in response to upset-induced external interference is morally impermissible in the absence of strong countervailing pragmatic reasons and attempts to reduce upset, and (3) potentially upsetting geoscience research ought to be communicated truthfully and tailored to each individual situation. These general propositions are applied to a case of ethical but upsetting research that we ourselves are currently involved.
\end{abstract}

\section{INTRODUCTION}

$\mathrm{G}$ eoscience research occasionally upsets people. In some instances, this is because it violates ethical norms. However, upset may also be caused by research that is perfectly ethically acceptable (abstracting from the fact that it upsets people, which may itself be ethically relevant). Examples of ethical but upsetting geoscience research include hydrocarbon explorations near populated areas (e.g., Vidic et al., 2013), seismological studies that indicate the possibility of major earthquakes (e.g., Moernaut et al., 2018) and interviews with the colleagues of mine workers who died during mining activities or strikes (e.g. Alexander et al., 2013).

In this paper we attempt to explore the following three questions: (1) Under what conditions, if any, is it ethically permissible to conduct ethical but upsetting geoscience research? (2) Under what conditions, if any, is it ethically permissible to revise one's research in response to interference by people outside the research who are upset by it? (3) How ought one to communicate ethical but upsetting research? We begin by explaining a case of ethical but upsetting geoscience research that led us to think about these questions. Referring to this case, each of the questions is then explored in turn. Our aim is not to develop fully comprehensive answers (i.e., to identify every factor that is relevant to answering the above questions with regard to every kind of upsetting geoscience research). Rather, we will specify several factors that in our view are important to the assessment of the particular case with which we are concerned. These considerations can hopefully serve as a useful starting point for assessing and dealing with other cases of ethical but upsetting geoscience research as well.

\section{THE EE-CON PROJECT: AN EXAMPLE OF ETHICAL BUT UPSETTING RESEARCH}

Both authors of this paper are involved in the Austrian Academy of Sciences project Economic 
and Ethical Consequences of Natural Hazards in Alpine Valleys (EE-Con).

Due to steep topographical relief, high population density and the economic importance of summer and winter tourism, the Alps and their population are particularly vulnerable to geomorphological and hydrological hazards. This problem might be amplified by rising temperatures and more pronounced precipitation events due to climate change. Focusing on two alpine valley regions in Austria, the Johnsbachtal and the Sölktäler, EE-Con addresses natural hazards by means of interdisciplinary cooperation between geographers, economists and philosophers. For example, we enquire into the causes, frequency and intensity of these hazards, as well as residents' perception and knowledge, the costs of protection from and adaptation to the hazards, compensation for losses, and the potential resettlement of (parts of) the valleys (e.g. Ortner et al., 2017).

There are good reasons for believing that the research involved in EE-Con is ethical (not the least of which is that the Austrian Academy of Sciences approved it). However, the project has caused significant upset. Shortly after EE-Con started, it was covered by Austria's largest daily newspaper. Following reports of past natural hazards in one of our study areas, as well as the possible impact of climate change, the last paragraph of the article addressed the theoretical option of abandoning parts of these areas. A member of the project team was quoted as follows: "from a purely economic perspective it may one day be reasonable to abandon villages (which are declining in population anyway). But of course, such a decision can never be exclusively grounded in economic considerations" (Kronen Zeitung, 2016).

This is quite a weak statement. In fact, it only states what may be reasonable at some unspecified point in future if one considers the matter from only one relevant perspective. Nevertheless, the above-mentioned article significantly upset residents of our study areas. Only one day after its publication, the mayor of one of the areas called the university and threatened to withdraw his cooperation, which was important for the project to be properly accomplished. As he explained to us, residents of the valleys simply did not want the option of relocation to be ex- amined in any way. It was, so to speak, a taboo issue for them.

In the days that followed, we prepared for an emergency meeting with the mayor and other local representatives. This led us to reflect on the ethical questions raised in the introduction, in particular: was it permissible for us to pursue this project at all? If the mayor requested significant revisions to our original research plan, to what extent ought we to comply with these requests? And how can research such as ours be communicated more appropriately?

\section{THE PERMISSIBILITY OF CONDUCTING ETHICAL BUT UPSETTING RESEARCH}

Our first question asks about the conditions under which ethical but upsetting geoscience research is ethically permissible. At first sight, the answer to this question may appear to be trivial: if the research at issue is ethical how could it ever be ethically impermissible to engage in it? Recall, however, that by "ethical" we here mean "ethical, abstracting from the fact that the research causes upset". This means that it is possible that the research at issue, even though ethical in all other respects, is impermissible precisely for the reason that it causes upset.

Since the geoscience research addressed in this paper is not unethical in itself, any upset caused by this research cannot be a response to it being unethical. The upset must rather be caused by non-moral facts related to the research (facts that make people interpret this research in a certain way, facts about people's specific nonbasic interests, etc.). In our view, this implication grounds a strong presumption for believing that ethical but upsetting geoscience research is generally permissible (compare Mill, 1998 on offence). It is possible for this presumption to be defeated. In practice, however, this will only rarely happen, as it would require very strong reasons for the research to be impermissible, and typically these reasons do not hold.

\section{EXPECTED RESEARCH OUTPUT}

One fact that may constitute a strong reason against the permissibility of ethical but upsetting geoscience research - in our view the most 
important one - concerns the expected output of the research. Suppose experts unequivocally agree that a study will not yield any significantly valuable output, either in terms of expanding our geoscience knowledge or in terms of informing action. Then the fact that this research upsets people may imply that the research ought not to be conducted. After all, it seems wrong to upset people for no good reason.

\section{REASONS FOR THE UPSET}

Even though ex hypothesi the research addressed here cannot upset people because it is unethical, there are still good and bad reasons for people getting upset. Consider our research about relocating communities. While this research may upset one person because he or she is genuinely concerned about having to leave and thus becoming unable to realize his or her life plans (a perfectly understandable reason), another person may be equally upset because of an insubstantial decrease in a financial investment that he or she made in the relevant area (a worse reason). In our view, upset can only possibly constitute a valid for not conducting ethical research to the extent that it is based on good reasons.

\section{NUMBER OF UPSET PEOPLE}

Suppose the above two conditions (low expected scientific value and good reasons for upset) are fulfilled. Then one among several further relevant factors that determine the permissibility of ethical but upsetting geoscience research is the number of people that this research upsets. The more people who are upset, the stronger one's reason for not conducting the research.

\section{DEGREE OF UPSET}

In related terms, the extent to which people are upset also matters. The more the geoscience research at issue upsets them, the stronger the reason not to engage in it.

\section{DISTRIBUTION OF RESEARCH BENEFITS}

Finally, assuming that the geoscience research at issue is at least somewhat valuable, it also matters who will benefit from this research. When the upset people themselves are not among the recipients of benefits - either directly or indirectly (for example, by having access to additional geoscience knowledge) - it is more difficult to justify the research than when they are among these recipients.

In most cases, geoscience research can be expected to yield valuable results. We accordingly would like to re-emphasize that the fact that a study provokes upset only very rarely implies that this study is impermissible. Such an implication does not hold with regard to EECon either. Admittedly, the upset caused by this project has to some extent been based on good reasons and has been strong. But it only affected a small number of people and, most importantly, the expected results of our project are valuable both in expanding our knowledge about natural hazards and in scientifically informing actions regarding the protection and potential resettlement of our study areas (thus benefitting the very people that the project upsets).

\section{THE PERMISSIBILITY OF REVISING ETHICAL BUT UPSETTING RESEARCH}

Let us suppose that an instance of ethical but upsetting geoscience research is permissible according to the above criteria. Occasionally, such as with EE-Con, research of this kind will nevertheless upset people to such a high degree that they demand revisions of this research. Our second geoethical question is under what conditions, if any, is it permissible for researchers to comply with such demands, i.e., to revise their research in response to upsetinduced external influences?

In answering this question, we assume the value of the autonomy (or, more broadly, the integrity) of science. Admittedly, the notion "autonomy of science" is quite vague. There is agreement, however, that the value entails that science as a social system should be selfgoverning. Within the domain of their expertise, and given certain practical limits, those who are part of this system should be free from external constraints (Resnik, 2008). In our view, the importance of the autonomy of science creates a presumption against revising one's research in response to external pressure caused by people who are upset. This presumption can 
only be defeated by strong reasons in favor of revisions.

\section{PERSISTENCE OF THE UPSET / INTERFERENCE}

For it to become possibly permissible to revise one's research in response to upset-induced interference, one would first have to attempt to alleviate this upset. Depending on the details of the case one might have for example, to inform the media (more clearly) about the aims of this research, initiate a public discussion, or schedule a private meeting. Only if serious attempts at mediation fail can it possibly become permissible to comply with requests for revision.

\section{SCIENTIFIC VALUE OF REVISED RESEARCH}

A further relevant factor in determining the permissibility of requested revisions is the nature and extent of these revisions. Sometimes, revisions can be implemented without significantly decreasing the expected value of the research. However, to the extent that this value is threatened, researchers should be much more reluctant to give in to external demands.

\section{COSTS OF NON-COMPLIANCE FOR RESEARCH}

In some cases, not complying with the upsetinduced request to revise one's research may lead to a complication or partial or complete termination of the research. For example, this may happen when revisions were requested by one's funding institution or by cooperation partners, or when subjects refuse to fill in questionnaires. Obviously, the higher the risk of complications and some degree of termination of the project the more permissible is it to make concessions to the people who are upset (within ethical boundaries).

\section{COSTS OF NON-COMPLIANCE FOR RESEARCHERS}

Finally, non-compliance may also involve serious costs for the researchers, who may be harassed or threatened, may lose the ability to acquire funding for future research, or lose their employment. The risk of such costs again renders it proportionately more permissible to conform to the upset people's requests for revisions (within ethical boundaries).
Because of the value of the autonomy of science, ideally, researchers would resist all upsetinduced external requests for altering their research. However, we acknowledge that in reality pragmatic considerations may sometimes outweigh this value by calling for compromises. In EE-Con, we concluded that, if requested, we would go at least some (but not all) way in accounting for the mayor's hypothesized request not to study the potential resettlement of communities. This is because with revisions, the part of the project that deals with resettlement would still have delivered valuable results, and so would the parts that do no deal with resettlement. Losing the support of the mayor would have involved a high risk of complicating aspects of our research and diminishing its value.

\section{THE COMMUNICATION OF ETHICAL BUT UPSETTING RESEARCH}

The extent to which potentially upsetting geoscience research actually upsets people depends significantly on how this research is communicated. If it is based on a well-thoughtout communication strategy, such research will typically provoke far less upset than if it is based on a bad or non-existing strategy (Stewart and Lewis, 2017).

\section{INFORMATION CONTENT}

One of the main determinants of whether research will upset people is what one communicates about it. In the case of potentially upsetting research, it might be tempting either to not inform people and stakeholders about potentially upsetting aspects, to downplay the importance of these aspects, or perhaps even to provide false information. But only in very rare cases would either of the first two options be morally permissible, and the third one certainly is not (see Charlton 2009; Di Capua et al. 2017). To begin with, truth is an intrinsic value that is of primary importance within science. Secondly, scientists have a social responsibility to adequately report their research to the public (especially when they are publicly funded). Thirdly, omissions, trivializations and lies may have all sorts of bad consequences, ranging from lawsuits and public distrust (in specific projects 
and in science in general) to harm to one's academic reputation.

\section{CLARITY OF INFORMATION}

While potentially upsetting research must generally be communicated truthfully, there are more and less appropriate ways of doing so. In many cases information about research upsets people because they misunderstand it. It is thus important that researchers state objectives, methods, results, uncertainties, and probabilities as clearly and intelligibly as possible. In particular, they should minimize both ambiguity (the existence of multiple meanings), vagueness (the existence of borderline cases in meaning) and the complexity of their explanations.

\section{TYPE OF COMMUNICATION}

Bultitude (2010) distinguishes three ways of communicating scientific research: traditional journalism (e.g., newspapers, radio and television), live or face-to-face events (e.g., public debates and lectures), and online interactions (e.g., websites and blogs). Each of these types has advantages and disadvantages. For example, while traditional journalism reaches large audiences and is generally perceived as trustworthy, it typically does not allow scientists to report their research in detail, does not give them much control over how it is presented, and prevents audiences from responding by comments or questions (Bultitude 2010; see also Foresta Martin and Peppoloni 2017). The appropriateness of researchers' communication strategies also significantly depends on how they choose the type of communication that best fits their respective situation.

\section{TIMING OF COMMUNICATION}

Suppose a person were informed that starting tomorrow, geologists will perform hydrocarbon explorations in the vicinity of his or her property. No doubt the person would become terribly upset - and rightly so. By not informing the person earlier, the researchers engaged in this project would have prevented him or her from gathering more information, publicly objecting to the explorations, coming to terms with the project, etc. Hence, the timing of the communication of potentially upsetting research matters as well. In particular, such re- search ought to be communicated as early as possible.

\section{RECIPIENTS OF INFORMATION}

Finally, the way in which potentially upsetting research is communicated must also be tailored to the recipients of the information. A fact sheet for experts of the Department of Agriculture, for example, requires a substantially different content and form (in terms of comprehensiveness, complexity, etc.) than does a fact sheet for the local population (Alexander, 2007; Marone et al., 2015; Stewart and Lewis, 2017).

These considerations suggest that developing an appropriate strategy for communicating potentially upsetting research is complex and highly dependent on its context. In retrospect, it seems that in the EE-Con project, we did not pay sufficient attention to this task. There probably would have been no need for us to address the resettlement aspect of our research in the newspaper interview mentioned above, as this is only one of several aspects of our project and the article did not aim for comprehensiveness. Rather, in communicating this aspect, we should have employed selective, live or face-to-face types of communication, and we should have done so at a much earlier point in time.

\section{CONCLUSIONS}

In this paper, we have arrived at three conclusions about ethical but upsetting geoscience research. First, under most circumstances such research is morally permissible. Secondly, revising this research in response to upsetinduced external interference is morally impermissible in the absence of strong countervailing pragmatic reasons and attempts to reduce upset. And thirdly, potentially upsetting research ought to be communicated truthfully and tailored to each individual situation.

Thinking about the above issues allowed us to draw valuable lessons with regard to EE-Con. In particular, we entered the next meeting with stakeholders with a clear strategy that included a plan of communication and a plan about how much to comply with potential requests for revision. Following constructive dialogue, the 
mayor and other representatives of the study areas agreed to the project's resettlement aspect after all and our research is well on the way.

\section{ACKNOWLEDGEMENTS}

This work was funded by the Austrian Academy of Sciences (OeAW) project Economic and Ethical Consequences of Natural Hazards in Alpine Valleys (EECon) and the Austrian Science Fund (FWF) under research grant W 1256-G15 (Doctoral Programme Climate Change - Uncertainties, Thresholds and Coping Strategies). For helpful comments we would like to thank David Alexander and the three reviewers of this paper.

\section{REFERENCES}

Alexander D. (2007). Making research on geological hazards relevant to stakeholders' needs. Quaternary International, 171-172, 186-192, doi.org/10.1016/j.quaint.2007.01.006.

Alexander P., Sinwell L, Lekgowa T., Mmope B. and Xezwi B. (2013). Marikana: A View from the Mountain and a Case to Answer. Bookmarks Publications, London. ISBN: 978-1909026285.

Bultitude K. (2010). Presenting Science. In: Brake M. and Weitkamp E. (eds.), Introducing Science Communication, Palgrave MacMillan, London, ISBN: 978-0230573864.

Charlton B.G. (2009). Are you an honest scientist? Truthfulness in science should be an iron law, not a vague aspiration. Medical Hypotheses, $73 \quad$ (5), 633-635. doi.org/10.1016/j.mehy.2009.05.009.

Di Capua G., Peppoloni S. and Bobrowsky P. (2017). The Cape Town Statement on Geoethics. Annals of Geophysics, 60, Fast Track 7, doi.org/10.4401/ag-7410.

Foresta Martin F. and Peppoloni S. (2017). Geoethics in communication of science: the relationship between media and geoscientists. Annals of Geophysics, 60, Fast Track 7, doi.org/10.4401/ag-7410.

Kronen Zeitung (2016). Klimawandel bedroht Alpenraum. Graz Extra, Issue: 9.03.2016, p. 19.

Marone E., Camargo R. and Salcedo-Castro J. (2015). Communicating natural hazards: marine extreme events and the importance of variability and forecast errors. In: Peppoloni S. and Di Capua G. (eds), Geological
Society London, Special Publications 419, 125-131, ISBN: 978-1862397262.

Mill J.S. (1998). Utilitarianism. New York, Oxford University Press, ISBN: 9780198751632.

Moernaut J., Van Daele M., Fontijn K., Heirman K., Kempf P., Pino M., Valdebenito G., Urrutia R., Strasser M. and De Batist M. (2018). Larger earthquakes recur more periodically: New insights in the megathrust earthquake cycle from lacustrine turbidite records in south-central Chile. Earth and Planetary Science Letters, 481, 9-19, doi.org/10.1016/j.epsl.2017.10.016.

Ortner F., Pölzler T., Meyer L. and Sass O. (2017). Natural hazards and the normative significance of expectations in protecting alpine communities. In: EGU (ed.): Geophysical Research Abstracts: Abstracts of the European Geosciences Union General Assembly, Munich, Copernicus.

Resnik D.B. (2008). Scientific Autonomy and Public Oversight. Episteme, 5 (2), 220-238, doi.org/10.3366/E1742360008000336.

Stewart I.S. and Lewis D. (2017). Communicating contested geoscience to the public: Moving from 'matters of fact' to 'matters of concern'. Earth-Science Reviews, 174, 122133, doi.org/10.1016/j.earscirev.2017.09.003.

Vidic R.D., Brantley S.L., Vandenbossche J.M., Yoxtheimer D. and Abad J.D. (2013). Impact of Shale Gas Development on Regional Water Quality. Science, 340, 826-835, doi.org/10.1126/science.1235009. 